\title{
ANALYSIS OF FACTORS THAT INFLUENCE THE INDEPENDENCE OF REGIONAL FINANCE IN WEST NUSA TENGGARA PROVINCE
}

\author{
Hendri Wira*, Utama Made Suyana \\ Faculty of Economics and Business, University of Udayana, Bali, Indonesia \\ ${ }^{*}$ E-mail: wirahendri@gmail.com
}

\begin{abstract}
This study analyzes the factors that influence the financial independence of the regencies or cities in the province of West Nusa Tenggara (NTB). The research variables used in this study is Per-capita Regional Revenue (PAD), Per-capita Fiscal Balance Funds, Per-capita Gross Domestic Product, population and regional financial independence. The analysis tool uses multiple regression models and Ordinary least Square (OLS) method. While, the data used is a data panel Regency or Cites in NTB for the last 5 years. The results of the analysis show that the PAD variable shows a positive and significant effect on regional financial independence. Fiscal Balance Funds variables have a negative and significant effect on regional financial independence. This is because Local Government reached 70 percent fund from the central government during the study period. The variable per capita GRDP does not have a positive and insignificant effect on regional financial independence. It causes by low contribution of the main sectors to the formation of GRDP which the mainstay of the regency or cities governments in the NTB province are, such as agriculture, plantation, agriculture, mining and excavation. The variable number of residents is not positive and not significant towards regional financial independence. Lower people's purchasing power will reduce the amount of goods and services purchased that effect to reducing the amount of money for the region.
\end{abstract}

\section{KEY WORDS}

Per-capita regional revenue, per-capita fiscal balance funds, per-capita regional gross domestic product, population, multiple regression.

Regional autonomy is the authority of the autonomous region to be given and requested by the community according to its own initiative based on the aspirations of the community accordance with the laws and regulations. An important issue in the renewal of regional autonomy is the distribution of shares or balances between the central and the regions. Financial balance between the central and the regions is very important and must pay attention to politics and economic justice. It is accordance with the general provisions in Law No. 22 of 1999 which was later approved by Law No. 32 of 2004 about Local Government and Law No. 25 of 1999 which was then approved by Law No. 33 of 2004 about Financial Balance between Central and Local Governments.

In Law Number 32 of 2004, the independence of local finance means that the government can carry out financing and financial accountability itself, implementing itself in the framework of the principle of decentralization. Regional financial independence can be seen from how much regional revenue compared to regional income from other sources such as central government assistance or from loans, besides PAD regional financial independence is also caused by many factors such as Regional Gross Domestic Product (PDRB), profit sharing funds, specific allocation funds, general allocation funds and population numbers.

Measuring the performance of local governments to improve the performance of local governments as holder of public sector policies in development and community service. One of the instruments to measure the performance of local governments on managing regional finance is by analyzing the financial ratios of the APBD that have been established and ratified. Although the use of ratio analysis as a financial analysis tool for local governments is still very limited, the results of financial ratio analysis of the APBD that have been determined 
and ratified by the regional government, can be used as a benchmark in: (1) Assess local financial independence on build regional autonomy implementation, (2) Measuring effectiveness and efficiency in realizing regional income. (3) Measuring which expenditures from local governments spend their regional expenditures. (4) Measuring the contribution of each source of income in the composition of regional income. (5) See growth or contributions made over a period.

West Nusa Tenggara Province as a province that has split also strives to carry out financial management better than before. Regional expansion according to Law No. 32 of 2004 is the formation of regions can be merging several regions or parts of regions that are coupled or divided from one area into two or more regions. In 2008 the number of regencies or cities in NTB was 10 regencies or cities. Previously there were 8 regencies or cities. The table is presented the regional financial independence ratio in NTB for 2012-2016.

Table 1 - Regional Financial Independence In The NTB Region In 2012-2016

\begin{tabular}{lcc}
\hline \multicolumn{1}{c}{ Regency or City } & $\begin{array}{c}\text { Average of Regional } \\
\text { Financial Independence (\%) }\end{array}$ & Criteria \\
\hline Bima Regency & 10,75 & Low \\
Dompu Regency & 10,57 & Low \\
Lombok Barat Regency & 22,57 & Low \\
Lombok Tengah Regency & 14,73 & Low \\
Lombok Timur Regency & 15,25 & Low \\
Sumbawa Regency & 14,45 & Intermediate \\
Mataram City & 32,3 & Low \\
Bima City & 5,5 & Low \\
Lombok Barat Regency & 10,07 & Low \\
\hline
\end{tabular}

Source: Department Keuangan, 2017 (Processed).

Based on Table 1, regional financial independence in the NTB Region in 2012-2016 is included in the very low criteria because the financial independence of the region is less than 25 percent except the city of Mataram with Intermediate criteria. This certainly needs special attention. This low criterion indicates that the local governments' ability to defray their own government activities, development and service to the community is still low. Therefore, it is necessary to know what factors influence regional financial independence.

According to Halim (2007), the existence of determinants of the size of regional financial independence is also supported by Nofiyanto (2005) showing that the structure of financial receipts in regency or cities in the Special Region of Yogyakarta is still dominated by donations and assistance from the central. The results of the same study also revealed Suprajitno (2003) indicating that the financial capacity of the local government of Banjarnegara Regency was still lacking, or it could be stated that the level of dependence on the central government was still quite high.

Research conducted by Muliana (2009) shows that PAD has a significant positive effect on the level of regional financial independence, while DAU and DAK have a significant negative effect on the level of financial independence of the regency or city in North Sumatra. Research by Ersyad (2011) found that in general, all regencies and cities in West Sumatra in 2006-2008 were still far from being said to be financially independent, the average independence ratio ranged from 3 percent to 10 percent. This means that the Regency or City governments in West Sumatra still depend on the central government to finance all the activities of their area.

The results of research by Putri (2014) show that GDP is one of the factors that influence Regional Financial Independence. Saragih (2003) in Putri (2014) said that the success of regional autonomy is measured by how much the contribution of local communities to regional economic growth or GDP. If the GRDP increases, this indicates an increase in local revenue. Darmanto (2012) who conducted research on local governments in Indonesia, showed that Population has a positive effect on Regional Financial Independence 
in Indonesia. But other studies show the opposite results, that Population (Patriati and Winarna, 2010), GRDP (Winarna, 2010) does not affect Regional Financial Independence.

Re-examination of the factors that influence the Independence of Regional Finance is carried out to identify what factors influence the Independence of Regional Finance, so that the improvement steps in the future are more directed. This study aims to determine the effect of PAD, fiscal balance funds, GRDP and number of populations on the level of financial independence of regencies and cities in NTB. The conceptual framework that describes the relationship between variables in this study can be seen in Figure 1.

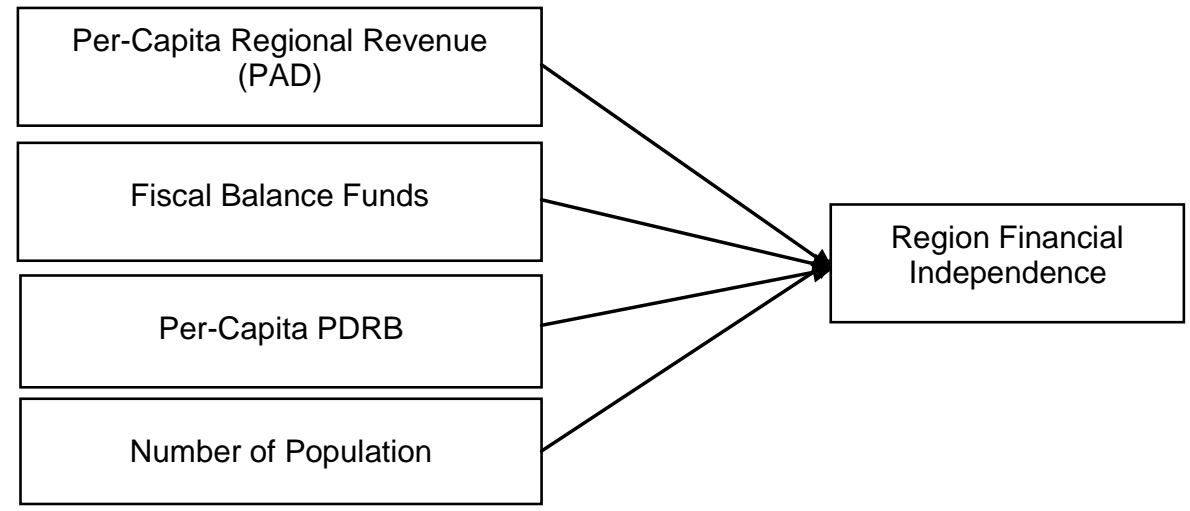

Figure 1 - Conceptual Framework

\section{METHODS OF RESEARCH}

This study uses a causative method, which is to find out and analyze the effect of GDP, Per-capita Regional Revenue (PAD), Fiscal Balance Funds and Number Population on the level of financial independence of the regency or city in NTB Province. The population used in this study is all regencies and cities in NTB. The determination of the sample is determined by the total sampling technique.

This study uses secondary data that obtained from the results of second-party processing or data obtained from the publication of other parties. Secondary data used in this study is panel data, which is a combination of cross-sectional data (cross section) and time series data (time series) from 2012-2016. The data needed in this study include, Budget Realization Reports respectively each regency or city in the NTB Region in 2012-2016, GRDP based on constant prices of 2000 regency or cities in the NTB Region in 2012-2016, Total Population based on the 2010 population census in each regency or city in the NTB Region. The methods used in data retrieval are documentation that collecting data obtained from relevant agencies.

The research variables used are the level of regional financial independence (Y), PAD $\left(X_{1}\right)$, Fiscal Balance Funds $\left(X_{2}\right)$, GRDP $\left(X_{3}\right)$, and Number Population $\left(X_{4}\right)$. This study uses a quantitative approach. The analysis technique used is descriptive analysis and statistical analysis to prove the research hypothesis. This study uses panel data regression analysis.

The level of regional financial independence is measured as follows:

$$
\text { TKKD }=\frac{P A D}{\text { Central or Province Government Assistance and Loan }} \times 100 \%
$$

Table 2 - Criteria for regional independence

\begin{tabular}{lll}
\hline Financial Ability & Independence Percentage & Relationship Pattern \\
\hline Very Low & $0-25$ & Instructive \\
Low & $25-50$ & Konsultative \\
Intermediate & $50-75$ & Participative \\
High & $75-100$ & Delegative \\
\hline
\end{tabular}

Source: Halim, 2004. 
Per-capita Regional Revenue $\left(\mathrm{X}_{1}\right)$ in this study is measured by looking for contributions to regional income with the formula:

$$
\mathrm{PAD}=\frac{P A D}{\text { Number of Population }}
$$

Fiscal Balance Funds $\left(\mathrm{X}_{2}\right)$. Fiscal Balance Funds in this study are measured by looking for contributions to regional income with the formula:

$$
\text { Fiscal Balance Funds }=\frac{\text { Fiscal Balance Funds }}{\text { Number } \text { of Population }}
$$

GRDP $\left(\mathrm{X}_{3}\right)$ : GRDP in this study is measured using per-capita GRDP on the basis of constant 2000 prices using the formula:

$$
\mathrm{PDRB}_{\text {percapita }}=\frac{P D R B \text { constant price } 2000}{\text { Number of Population }}
$$

Total Population $\left(\mathrm{X}_{4}\right)$, Population in this study is the total population in the Regency or City in the NTB Region. This study refers to the Population projection based on the 2000 population census, the 2010 population census and the results of projections based on the 2010 population census by Regency or City in the NTB Region.

\section{RESULTS AND DISCUSSION}

Based on data processing, multiple regression equations are obtained as:

$$
\mathrm{Y}=8,13+0,017\left(\mathrm{X}_{1}\right)-0,001\left(\mathrm{X}_{2}\right)+5,39\left(\mathrm{X}_{3}\right)+0.003\left(\mathrm{X}_{4}\right)
$$

Where: $Y=$ Level of Regional Financial Independence (in Percentage); $X 1=$ PAD per capita (in thousands of rupiah); X2 = Percentage Balance Funds (in thousand Rupiahs); X3 = GDP per capita (in thousand Rupiah); X4 = Population (thousands of people); $\mathrm{e}=$ error.

The PAD variable (X1) has a significant positive direction of 0.017 and $0.0493 \leq \alpha=$ 0.05 , meaning that if the PAD increases by one thousand rupiah, regional independence increases by 0.017 percent if it is assumed the Fiscal Balance Fund, GRDP and Number of Population are zero. The Fiscal Balance Funds variable (X2) has a significant effect with a negative direction of 0.001 and $0.0309 \leq \alpha=0.05$, meaning that if the balance fund rises by one thousand-rupiah, regional independence decreases by 0.001 percent if assumed PAD, GRDP and Number of Population are zero.

GDP variable (X3) does not have a significant effect with positive direction of 5.39 and $0.3563 \leq \alpha=0.05$. this means that if the GRDP increases by one thousand rupiah, then regional financial independence rises by 5.39 percent if it is assumed that the Fiscal Balance Funds, PAD and Number of Population are equal to zero. The Population Amount variable (X4) has no significant effect with positive positive direction of 0.003 and $0.4219 \geq \alpha=0.05$. this means that if the population increases by 1,000 people then regional independence rises by 0.003 percent if it is assumed that PAD, Fiscal Balance Funds and GRDP are equal to zero. The measurement results of the coefficient of determination show an adjusted $R^{2}$ value of 0.8356 . This indicates that 83.56 percent of the variation in regional financial independence is explained by the PAD, Fiscal Balance Funds, GDP and Number of Population variables. While the remaining 16.44 percent is explained by other factors outside the research model such as grants, loans and others.

The results of the study showed that the Per-capita Regional Revenue (PAD) had a significant effect on the level of regional financial independence in NTB Province and supported the hypothesis proposed previously which stated that PAD had a positive and significant effect on regional independence in NTB. This finding supports the results of Ersyad (2011) research in Regency or Cities in West Sumatra which found that Per-capita Regional Revenue (PAD) had a positive and significant effect on the level of regional 
financial independence. This shows that the regency or city governments in NTB have succeeded in optimizing the sources of PAD owned to finance their regional expenses. Sources of income such as regional taxes, regional levies, separated income from wealth proceeds and other legitimate PAD until now continue to be optimized by regency or city governments in NTB.

If the PAD of a region is greater than the assistance of the central or provincial government and loans, the area is already financially independent so that the local government can reduce the allocation of the balance funds to the area. Conversely, if a region's PAD is smaller than the regional loan and central or provincial government assistance such as Revenue Sharing Fund (DBH), General Allocation Funds (DAU) and Specific Allocation Funds (DAK), the area is said to be financially independent because the area is still dependent on the central government. In implementing regional autonomy, financial resources originating from local revenues are more important than other sources of income because PAD is a regional financial resource that is extracted in the region concerned so that the optimization of PAD sources needs to be done to improve regional financial capacity.

The results of this study indicate that the balance fund has a negative and significant effect on the level of financial independence of the Regency or City in NTB. This finding shows that the greater the balance fund given by the central to the Regency or City in NTB, the lower the level of regional independence on managing its finances or in other words, the Regency or City in NTB still depends on central assistance in managing the independence of the region. This finding also supports the hypothesis proposed previously that Fiscal Balance Funds have a negative and significant effect on regional independence in NTB. The same results were also supported by research by Nofiyanto (2005) in the Special Regencies and Cities of Yogyakarta in 1994-2003, finding that the structure of financial receipts in regencies or cities in the Special Region of Yogyakarta was still dominated by donations and assistance (DAU and DAK) from the central. The significance of the Fiscal Balance Funds influencing regional independence in NTB based on the results of the analysis is more due to the high dependence of each regency or city on funding from the central. This is proven Based on the research period from 2012-2016 by dividing the total balance funds with the total Regional income of regencies or city in NTB, the amount of regional dependency is almost 70 percent of total regional income. The sources of balance funds are still dominated by the General Allocation Fund, Revenue Sharing Funds, Specific Allocation Funds which are the main sources of regional income.

Based on the results of data analysis shows that the variable per-capita GRDP does not significantly influence the Regency or City Financial Independence in NTB. This finding rejects the hypothesis put forward that per-capita GRDP has a positive and significant effect on regional financial independence. This result is inconsistent with the results of a study by Putri (2014) saying that the higher the level of GRDP indicates that the economic growth of the regional government is high and the welfare of the community increases. Not significant The GDP affects regional independence due to the low contribution of the main sectors of the formation of GRDP which the mainstays of the Regency or City in NTB are so far, such as the agriculture, plantation, and fisheries, mining and quarrying sectors. Based on the research period from 2012-2016, the average contribution of the agriculture, plantation and trade sectors to the formation of the GRDP only reached 23.56 percent, while the mining and quarrying sector only amounted to 17.96 percent, much lower than the target set by the government area 50 percent for agriculture, plantation and trade sector and 30 percent for mining and quarrying sector (BPS NTB, 2016). This can be seen in the table 3 :

Table 3 - Percentage distribution of GDP based on constant prices according to business fields in West Nusa Tenggara Province (percent)

\begin{tabular}{lllllll}
\hline Business Fields & 2012 & 2013 & 2014 & 2015 & 2016 & Average \\
\hline Agriculture, Forestry and Fisheries & 24,73 & 24,28 & 24,14 & 20,95 & 23,7 & $\mathbf{2 3 , 5 6}$ \\
Mining and excavation & 16,26 & 16,16 & 15,36 & 20,58 & 21,45 & $\mathbf{1 7 , 9 6 2}$ \\
\hline
\end{tabular}

Source: BPS NTB, 2017 (Processed). 
If the production of goods and services in the agriculture, forestry and fisheries and mining and quarrying sectors gives a high value of contribution, for example above 50 percent, the contribution to the GRDP will be higher, which in turn will provide an additional increase in regional revenues. Likewise, if the contribution is low, it will reduce regional revenues.

In general, each region has enough natural resources and even very potential, but if it is not used properly, the results will be futile. In implementing regional autonomy, increasing PAD does not necessarily emphasize the acquisition of regional taxes and retributions because it will indirectly burden the community with the aim of achieving targets from taxes and levies. The government must be able to continue thinking to manage the potential of existing natural resources by maximizing the existing human resources with training or by bringing in foreign experts in return for services in accordance with the prevailing provisions.

Testing the Population Number variable shows that the Population Number has no significant effect on Regional Financial Independence in NTB. This finding also rejects the previously stated Hypothesis that Population has a significant effect on regional financial independence. This result is the same as the findings made by previous researchers, Darmanto (2012) that an increase in population will reduce people's purchasing power in the region. Decreasing public purchasing power will reduce the amount of goods and services produced in the economy so that it has an impact on decreasing income for the regions, decreasing regional income resulting in lower regional capacity to manage finances. In addition, the population occupying an area will also affect the services provided by the regional government. If the number of populations becomes greater, it will require regional governments to improve public services better. Meanwhile, the ability of regions to provide public facilities is increasingly limited. So, service to the community becomes less optimal. The increase in demands has made it difficult for the government to improve performance (in this case regional financial independence) in providing services to the community.

\section{CONCLUSION AND RECOMMENDATIONS}

Regency or City Governments in NTB have succeeded in optimizing the sources of PAD owned to finance their regional expenditures. The dependence of each Regency or City of West Nusa Tenggara Province (NTB) is high on funding assistance from the central which reached 70 percent during the study period. The contribution of the main sectors to the formation of the GRDP, which has been the mainstay of the Regency or City governments in the Province of West Nusa Tenggara (NTB), such as the agriculture, plantation and fisheries, mining and quarrying sectors are still low. Population does not have a significant effect on regional financial independence in regencies or cities in West Nusa Tenggara (NTB) Province due to a decrease in people's purchasing power.

Local governments must continue to strive to increase revenues through intensification, external-strengthening and use of the budget effectively, efficiently so that it reduces dependence from the central government gradually. The government needs to strive to increase the achievement of the GRDP target annually so that regional revenues increase so that the regions can manage their regional finances. Population growth must be suppressed and balanced with improvements in the quality of the population itself, to create a quality population and increase regional financial independence.

\section{REFERENCES}

1. Badan Pusat Statistik. 2011. NTB Dalam Angka 2012-2016. BPS NTB

2. Darmanto, Habib Candra. 2012. Pengaruh Population, Employment, Size and Leverage Terhadap Kinerja Keuangan Pemerintah Daerah di Indonesia. Skripsi. Universitas Sebelas Maret.

3. Ersyad, Muhammad. 2011. Pengaruh Pendapatan Asli Daerah, Dana Alokasi Umum, Dana Alokasi Khusus terhadap Tingkat Kemandirian Keuangan Daerah (Studi Empiris pada Kabupaten and Kota di Sumatera Barat). Skripsi. FE UNP: Padang. 
4. Halim, Abdul. (penyunting). 2004. Bunga Rampai Manajemen Keuangan Daerah Edisi Revisi. Yogyakarta: UPP AMP YKPN.

5. Insukindro, dkk. 2001. Modul Ekonometrika Dasar and Penyusunan Indikator Unggulan Ekonomi. Workshop Ekonometrika Dalam Rangka Penjajakan Leading Indikator Export Di KTI.

6. Mardiasmo. 2002. Otonomi and Manajemen Keuangan Daerah. Yogyakarta: Andi Offset.

7. Muliana. 2009. Pengaruh Rasio Pendapatan Asli Daerah (PAD), Dana Alokasi Umum (DAU), and Dana Alokasi Khusus (DAK) Terhadap Tingkat Kemandirian Keuangan Daerah Pada Pemerintahan Kabupaten/ Kota Di Sumatera Utara, Skripsi USU: Medan

8. Noviyanto, Haris. 2005. Analisis Perimbangan Keuangan Pusat-Daerah and Pinjaman Daerah di Kabupaten and Kota Daerah Istimewa Yogyakarta Tahun 1994/1995-2003. Skripsi. FE Universitas Islam Indonesia.

9. Putri, Titin Kartika. 2014. Pengaruh Produk Domestik Regional Bruto (PDRB) Terhadap Kemandirian Fiskal Daerah Kabupaten Jember. Artikel Ilmiah. Universitas Jember.

10. Samuelson, and Nordhaus. 2004. Ilmu Makro Ekonomi (Edisi Terjemahan) Edisi Tujuh Belas. Jakarta: PT Media Global Edukasi.

11. Saragih, Juli Panglima. 2003. Desentralisai Fiskal and Keuangan Daerah Otonomi. Ghalia Indonesia: Jakarta.

12. Sadono Sukirno. 2006. Ekonomi Pembangunan (Edisi Kedua). Jakarta: Kencana.

13. Suprajitno, Pudji. 2003. Analisis Faktor-Faktor yang Mempengaruhi Kemandirian Fiskal Daerah (Studi Kasus di Kabupaten Banjarnegara). Tesis Pasca Sarjana Universitas Diponegoro: Semarang.

14. Todaro, and Smith. 2003, Economic Development, Eighth Edition, United Kingdom: Pearson Education Limited.

15. Wijaya, H.A.W. 2007. Otonomi Daerah and Daerah Otonomi. Jakarta: PT Raja Frafindo Persada.

16. Winarna, Jaka. 2010. Analisis Kinerja Keuangan Pemerintah Daerah di Jawa Tengah. Journal of Rural and Development. Vol. 1 No. 2, Agustus 2010.

17. Electronic source: www.bps.go.id

18. Electronic source: www.depkeu.go.id 